\title{
KEABSAHAN AKTA JUAL BELI TANAH YANG DIBUAT BERDASARKAN KUASA MENJUAL YANG TELAH DIBATALKAN PARA PIHAK (Analisis Putusan Pengadilan Negeri Denpasar Nomor 347/Pdt.G/2014/PN.Dps)
}

\author{
Dwi Apriliana \\ Magister Kenotariatan, Fakultas Hukum, Universitas Narotama Surabaya \\ Email : april.jurnal2018@gmail.com
}

\begin{abstract}
The economic value of land that is increasingly increasing gives birth to many problems related to land. One example of a problem that occurs related to land is in the Decision of the Denpasar District Court Number 347 / Pdt.G / 2014 / PN.Dps. In this case, the sale and purchase of rights to land occurred using the Deed of Agreement on the Sale and Purchase and the Deed of Selling, which had previously been canceled by the parties.

The author in this study wants to examine and analyze further about the Decision Ratio Decision of the Denpasar District Court Number 347 / Pdt.G / 2014 / PN.Dps and the Notary / Officials Acting Land Deed for Plaintiff's losses arising from the Decision of Denpasar District Court Number 347 /Pdt.G/2014/PN.Dps.

The research method used is normative legal research, namely legal research carried out by examining library materials or secondary legal materials while the problem approach is carried out using a legal approach and conceptual approach.

The results showed that the cancellation of the sale and purchase agreement and the cancellation of the selling authorization resulted in the power of attorney not authorized to do any form of legal action on behalf of the authorizer and any legal actions taken by the proxy on behalf of the authorizer after the cancellation were legal and void. by law. The Notary / Official of the Land Deed in making the deed is only based on formal evidence and there is no obligation to investigate materially the evidence presented by the viewers as a basis for making a deed.
\end{abstract}

Keywords: Agreement to Buy and Sell, Authorization to Sell, Liability

\begin{abstract}
ABSTRAK
Nilai ekonomis tanah yang semakin lama semakin meningkat melahirkan banyak sekali permasalahan yang berkaitan dengan tanah. Salah satu contoh permasalahan yang terjadi berkaitan dengan pertanahan terdapat pada Putusan Pengadilan Negeri Denpasar Nomor 347/Pdt.G/2014/PN.Dps. Pada perkara tersebut terjadi jual beli hak atas tanah dengan menggunakan Akta Perjanjian Pengikatan Jual Beli dan Akta Kuasa Menjual yang sebelumnya telah dibatalkan oleh para pihak.

Penulis dalam penelitian ini ingin menelaah dan menganalisa lebih lanjut tentang Ratio Decidendi Putusan Pengadilan Negeri Denpasar Nomor 347/Pdt.G/2014/PN.Dps dan tanggung gugat Notaris/Pejabat Pembuat Akta Tanah atas kerugian Penggugat yang timbul dari Putusan Pengadilan Negeri Denpasar Nomor 347/Pdt.G/2014/PN.Dps.

Metode penelitian yang digunakan adalah penelitian hukum normatif, yaitu penelitian hukum yang dilakukan dengan cara meneliti bahan pustaka atau bahan
\end{abstract}


hukum sekunder sedangkan pendekatan masalah dilakukan dengan menggunakan pendekatan undang-undang dan pendekatan konseptual.

Hasil penelitian menunjukkan bahwa adanya pembatalan perjanjian pengikatan jual beli dan pembatalan pemberian kuasa menjual mengakibatkan penerima kuasa tidak berwenang melakukan segala bentuk perbuatan hukum atas nama pemberi kuasa dan segala perbuatan hukum yang dilakukan oleh penerima kuasa atas nama pemberi kuasa setelah adanya pembatalan adalah cacat hukum dan batal demi hukum. Notaris/Pejabat Pembuat Akta Tanah dalam membuat akta hanya didasarkan kepada bukti formal saja dan tidak ada kewajiban untuk menyelidiki secara materiil alat bukti yang diajukan para penghadap sebagai dasar dibuatnya akta.

Kata Kunci : Perjanjian Pengikatan Jual Beli, Kuasa Menjual, Tanggung Gugat

\section{LATAR BELAKANG}

Tanah merupakan salah satu bagian dari kekayaan alam yang ada di bumi yang sangat vital keberadaanyya bagi semua kehidupan di bumi khususnya bagi manusia. Tanah memiliki nilai tinggi karena mempunyai peran serta fungsi penting dan tidak dapat dipisahkan dari kehidupan manusia. Kebutuhan akan tanah menjadi kebutuhan yang melekat dan tidak dapat dipisahkan dari kehidupan manusia sehingga membuat manusia cenderung memiliki keinginan untuk menguasai dan memiliki tanah.

Nilai ekonomis tanah yang semakin lama semakin meningkat melahirkan banyak sekali permasalahan yang berkaitan dengan tanah. Salah satu contoh permasalahan yang terjadi berkaitan dengan pertanahan terdapat pada Putusan Pengadilan Negeri Denpasar Nomor 347/Pdt.G/2014/PN.Dps antara RRE sebagai Penggugat melawan IPS sebagai Tergugat. Pada perkara tersebut Tergugat membutuhkan tambahan modal usahanya mengajukan permohonan kredit pada bank, namun bank mensyaratkan Tergugat memiliki izin usaha dan mempunyai rekening pada bank yang bersangkutan.

Berbekal bidang tanah SHM No. 5832 dan SHM No. 6533 yang dapat digunakan sebagai jaminan kredit, Tergugat meminta bantuan INW untuk membantu mengajukan kredit, dengan syarat Sertipikat dua bidang tanah tersebut dibalik namakan dari nama Tergugat menjadi atas nama INW. Tergugat menyetujui kemauan INW disertai janji bahwa balik nama Sertipikat tanah sifatnya hanya Formalitas saja, dan dua tanah tanah tetap menjadi milik Tergugat, jika pinjaman Kredit di bank sebesar Rp.1.000.000.000,- (satu milyar) sudah lunas terbayar. INW selanjutnya mengajak Tergugat menghadap Notaris, untuk membuat akta, oleh Notaris dibuatkan Akta Perjanjian Pengikatan Jual beli dan Akta Kuasa Untuk Menjual antara Tergugat sebagai penjual/ pemberi kuasa dan INW sebagai pembeli/penerima kuasa atas obyek sengketa I dan obyek sengketa II.

Setelah Sertipikat dua bidang tanah beralih nama menjadi atas nama INW, ternyata janji INW untuk mencarikan Tergugat Pinjaman/Kredit Bank tidak terealisasi, karena sampai dengan Januari 2008 janji INW untuk mencarikan Tergugat Pinjaman/Kredit Bank tidak terealisasi, maka Tergugat dan INW datang menghadap Notaris kembali untuk membatalkan kedua akta Perjanjian Pengikatan Jual Beli dan Akta Kuasa Untuk Menjual. Atas permintaan Tergugat dan INW 
selanjutnya Notaris membuatkan Akta Pembatalan atas perjanjian Pengikatan Jual beli dan Akta Kuasa Untuk Menjual.

Dari adanya pembatalan perjanjian pengikatan jual beli dan kuasa menjual tersebut sertipikat belum diserahkan oleh INW kepada Tergugat dan INW berjanji paling lambat 1 (satu) bulan akan menyerahkan sertipikat tanah sengketa dan tanah tersebut. Namun selanjutnya ternyata tanpa sepengetahuan dari Tergugat, INW telah membalik nama obyek sengketa I dan Obyek sengketa II menjadi atas namanya dan selanjutnya menjual dua bidang obyek sengketa kepada Penggugat.

Dalam jual beli antara INW dan Penggugat tersebut telah dilakukan sesuai dengan prosedur dalam jual beli hak atas tanah seperti halnya melakukan pengecekan ke Kantor Pertanahan Kota Denpasar, yang hasinya menyatakan Obyek sengketa yang akan diperjual belikan bersih tidak ada hak-hak yang membebaninya dan tidak pula ada Sita jaminan serta jual beli tersebut telah dilakukan dihadapan Pejabat Pembuat Akta Tanah untuk selanjutnya diterbitkan sertifikat atas nama Penggugat.

Penggugat yang merasa tidak mengetahui adanya permasalahan antara Tergugat dengan INW selanjutnya mengajukan gugatan karena tidak dapat menguasai obyek sengketa yang telah dibelinya dari INW namun masih dikuasai oleh Tergugat. Adapun alasan dari tergugat tidak mau mengosongkan obyek sengketa karena Tergugat merasa Perjanjian Pengikatan Jual Beli yang telah dibuatnya dengan INW telah dilakukan pembatalan dengan Akta Notaris sehingga dengan demikian haknya tidak beralih dan obyek sengketa tersebut masih milik penggugat.
Atas adanya gugatan tersebut Pengadilan Negeri Denpasar melalui Putusan Nomor 347/Pdt.G/2014/PN.Dps telah memutus bahwa Akta Pembatalan Perjanjian Pengikatan Jual Beli dan Kuasa Jual yang dibuat antara Tergugat dan INW adalah sah dan mengikat sehingga akibatnya jual beli yang dilakukan antara INW dengan Penggugat adalah cacat hukum dan batal demi hukum.

\section{RUMUSAN MASALAH}

1) Apa Ratio Decidendi Putusan Pengadilan Negeri Denpasar Nomor 347/Pdt.G/2014/PN.Dps?

2) Apakah Notaris/Pejabat Pembuat Akta Tanah bertanggung gugat atas kerugian Penggugat yang timbul dari Putusan Pengadilan Negeri Denpasar Nomor 347/Pdt.G/2014/PN.Dps?

\section{METODE PENELITIAN}

Metode yang digunakan dalam penelitian ini adalah metode penelitian yuridis normatif yang menekankan pada norma-norma hukum dengan menganalisa peraturan perundangundangan terkait. Dalam Penelitian ini peneliti menggunakan dua metode pendekatan masalah yaitu : 1) Statute Approach, pendekatan dengan menelaah semua peraturan perundang-undangan yang bersangkut paut dengan permasalahan (isu hukum) yang sedang dihadapi. 2) Conseptual Approach, yaitu pendekatan yang beranjak dari pandangan-pandangan dan doktrindoktrin yang berkembang di dalam ilmu hukum. ${ }^{1}$

1 Peter Mahmud Marzuki,Penelitian Hukum, Kencana Prenada Media, Jakarta, 2010, hal. 95-97 


\section{PEMBAHASAN}

\section{Ratio Decidendi Putusan Pengadilan Negeri Denpasar Nomor 347/Pdt.G/2014/PN.Dps}

Pertimbangan hakim atau Ratio Decidendi adalah argumen atau alasan yang dipakai oleh hakim sebagai pertimbangan hukum yang menjadi dasar sebelum memutus perkara. ${ }^{2}$ Dalam prakteknya hakim memiliki kebebasan dalam menyelesaikan perkara yang dihadapkannya. Adapun bebas dalam hal ini adalah kekuasaan yang merdeka juga adalah bebas dalam memeriksa dan mengadili perkara dan bebas dari campur tangan berbagai pihak seperti campur tangan pemerintah bahkan atasan hakim yang bersangkutan dan bahkan tuntutan yang dimohonkan penuntut umum saat persidangan sampai dengan adanya putusan hakim.

Putusan Hakim menurut Sudikno Mertodikusumo adalah suatu pernyataan yang oleh Hakim, sebagai pejabat Negara yang diberi wewenang untuk itu, diucapkan dipersidangan dan bertujuan untuk mengakhiri atau menyelesaikan suatu perkara atau sengketa antara para pihak. ${ }^{3}$ Putusan hakim yang ideal adalah putusan yang tidak menimbulkan masalah artinya kualitas dari putusan hakim berpengaruh terhadap lingkungan masyarakat dan kewibawaan serta kredibilitas dari lembaga peradilan dan juga mencerminkan nilai keadilan dan kepastian hukum.

Dalam pertimbangan hukum yang dikemukakan oleh Hakim dalam Putusan Pengadilan Negeri Denpasar Nomor 347/Pdt.G/2014/PN.Dps,

2 Rusli Muhammad, Hukum Acara Pidana Kontemporer, Citra Aditya Bakti, Bandung, 2010, hal. 193

${ }^{3}$ Sudikno Mertodikusumo, Hukum Acara Perdata, Liberty, Yogyakarta, 1998, hal. 167
Tergugat didalam jawabannya telah membantah telah terjadi jual beli terhadap obyek sengketa INW maupun kepada Penggugat. Berdasarkan bukti yang diajukan tergugat yang terjadi adalah Tergugat terbukti telah mengikatkan diri dengan INW untuk menjual sebidang tanah SHM melalui dibuatnya Akta Perjanjian Pengikatan Jual Beli dan Kuasa Menjual. Adapun atas Akta Perjanjian Pengikatan Jual Beli dan Kuasa Menjual tersebut selanjutnya dibuat Akta Pembatalan oleh Tergugat dan INW karena INW tidak dapat memenuhi janji untuk mencairkan kredit untuk Tergugat. Dengan adanya pembatalan tersebut maka sejak tanggal dibuatnya Akta Pembatalan maka segala Akta yang dibuat sebelumnya dinyatakan tidak berlaku dan tidak mempunyai kekuatan hukum, sehingga atas segala perbuatan hukum yang dilakukan berdasarkan Akta Kuasa Menjual yang telah dibuat sebelumnya menjadi batal demi hukum.

Hubungan antara individu yang merupakan subjek hukum ataupun badan hukum merupakan suatu hubungan hukum yang dapat dikategorikan sebagai perbuatan hukum. Salah satu bentuk dari perbuatan hukum tersebut adalah perjanjian. Perjanjian dapat dibuat secara bebas, bebas dalam artian untuk mengadakan perjanjian dengan siapapun, bebas menentukan bentuknya, bebas menentukan syaratsyarat, dan bebas untuk menentukan bentuknya.

$$
\text { Berdasarkan Pasal } 1320
$$

KUHPerdata untuk sahnya suatu perjanjian, perlu dipenuhi empat syarat yaitu:

1. Kesepakatan mereka yang mengikatkan dirinya

Kesepakatan antara para pihak yang membuat perjanjian yang mana terjadinya pertemuan atau kesesuaian kehendak diantara para 
pihak, dan kesepakatan tersebut harus diberikan secara bebas, artinya bebas dari paksaaan dan kekhilafan dan penipuan sebagaimana yang tercantum dalam Pasal 1321 KUHPerdata.

2. Kecakapan untuk membuat suatu perikatan

Diatur dalam Pasal 1330 KUHPerdata dimana kecakapan dari sahnya suatu perjanjian yang dibuat oleh para pihak.

3. Suatu hal tertentu;

Hal tertentu maksudnya adalah objek perjanjian atau prestasi yang diperjanjikan harus jelas, dapat dihitung dan dapat ditentukan jenisnya.

4. Suatu sebab yang halal.

Dalam pasal 1337 KUHPerdata menyatakan bahwa suatu sebab adalah terlarang, apabila dilarang oleh undang-undang, atau apabila berlawanan dengan kesusilaan baik atau ketertiban umum.

Salah satu bentuk perjanjian yang banyak dijumpai adalah jual beli, baik jual beli benda bergerak maupun jual beli benda tidak bergerak misalnya jual beli tanah. Berkaitan jual beli hak atas tanah, Boedi Harsono, menyatakan bahwa ada 2 (dua) syarat yaitu syarat materiil dan syarat formil. ${ }^{4}$ Untuk Syarat materiil menentukan sahnya jual beli tanah, yaitu:

1) Penjual berhak, berwenang dan boleh menjual atas tanah yang bersangkutan. Berhak dalam arti menguasai bidang tanah tersebut dapat dipakai dalam arti fisik, juga dalam arti yuridis, juga aspek privat dan bersepek publik.

4 Boedi Harsono, Hukum Agraria Indonesia (Sejarah Pembentukan UndangUndang Pokok Agraria Isi dan Pelaksanaannya), Djambatan,Jakarta, 2008, hal. 109.
2) Pembeli memang berhak dan berwenang untuk membeli, artinya merupakan subyek hukum yang diperbolehkan untuk memiliki hak atas tanah yang dibelinya.

3) Adanya hak atas tanah yang dapat diperjualbelikan karena memang milik sah penjual, tidak sedang berada dalam perselisihan. Adanya hak atas tanah yang dijadikan obyek jual beli, dan bidang tanah yang dijadikan obyek jual beli tidak dalam sengketa. ${ }^{5}$

Dari rumusan mengenai sayarat materiil sebagaimana tersebut diatas dapat dirumuskan bahwa, Pertama, hak menguasai atas tanah berisi serangkaian wewenang, kewajiban dan/atau larangan bagi pemegang haknya untuk berbuat sesuatu mengenai tanah yang dihaki. ${ }^{6}$ Sesuatu yang boleh, wajib atau dilarang untuk berbuat yang merupakan isi hak penguasaan, itulah yang menjadi kriterium atau tolok ukur pembeda di antara hak-hak penguasaan atas tanah yang diatur dalam hukum tanah. Pemilik hak atas tanah dalam menguasai bidang tanah memperoleh perlindungan hukum, termasuk jika mengalihkan hak atas tanah tersebut yakni mempunyai hak untuk mengalihkannya. Sebagaimana ketentuan pasal 1471 KUH Perdata bahwa jual beli atas barang orang lain adalah batal dan dapat memberikan dasar kepada pembeli untuk menuntut penggantian biaya, kerugian dan bunga, jika ia tidak mengetahui bahwa barang itu kepunyaan orang lain.

Kedua, mengenai kewenangan pembeli untuk membeli hak atas tanah

${ }^{5}$ Hatta Isnaini Wahyu Utomo, "Hukum Tanah Nasional : Bahan Diskusi Dalam Persiapan Menghadapi Ujian Pejabat Pembuat Akta Tanah 2017", Makalah, disampaikan pada acara Persiapan Menghadapi Ujian PPAT 2017, Universitas Narotama Surabaya, Oktober 2017, hal. 18

${ }^{6}$ Boedi Harsono, Op.Cit., hal. 24. 
berkaitan dengan larangan warga negara asing untuk menguasai hak milik atas tanah atau hak guna bangunan dan larangan pembeli sebagai pembeli yang memiliki tanah melebihi luas batas pemilikan hak atas tanah sebagaimana diatur dalam Pasal 17 ayat (1) UndangUndang Nomor 5 Tahun 1960 Tentang Peraturan Dasar Pokok-Pokok Agraria (UUPA).

Ketiga, adanya kesepakatan para pihak (penjual dan pembeli) untuk melaksanakan jual beli hak atas tanah. Perihal kesepakatan mereka yang mengikatkan dirinya dalam jual beli hak atas tanah. bermakna bahwa "para pihak yang membuat perjanjian telah sepakat atau ada persesuaian kemauan atau saling menyetujui kehendak masingmasing, yang dilahirkan oleh para pihak dengan tiada paksaan, kekeliruan atau penipuan". ${ }^{7}$ Dengan demikian dikatakan terdapat kata sepakat bagi yang membuat perjanjian apabila ada kemauan yang bebas dalam arti perjanjian dibuat tanpa adanya paksaan, penipuan maupun kekhilafan. Perihal sepakat dalam perjanjian, tunduk pada asas konsensual, maksudnya sepakat kedua belah pihak telah melahirkan perjanjian.

Selanjutnya mengenai syarat formil mengenai jual beli khususnya hak atas tanah berhubungan dengan prosedur jual beli hak atas tanah agar jual beli tersebut sah menurut hukum. Diundangkannya UUPA dan Peraturan Pemerintah Nomor 24 Tahun 1997 Tentang Pendaftaran Tanah (PP No. 24 Tahun 1997) sebagai peraturan pelaksanaan, ketentuan hukum adat tersebut berlaku untuk jual beli hak atas tanah menurut UUPA dan mengingat Pasal 37 ayat (1) PP No. 24 Tahun 1997 maka saat beralihnya hak atas tanah dari

7 Riduan Syahrani, Seluk Beluk dan Asas-Asas Hukum Perdata, Alumni, Bandung, 1989, hal. 214) penjual kepada pembeli ialah ketika dilakukan jual beli oleh dan dihadapan PPAT. Akan tetapi karena tidak semua jual beli hak atas tanah dilakukan oleh dan dihadapan PPAT dan akta PPAT itu mengikat apabila jual beli telah memenuhi persyaratan materiil, maka beralihnya hak dalam jual beli hak atas tanah ialah ketika jual beli itu terjadi baik dilakukan oleh dan dihadapan PPAT dengan telah terpenuhinya syarat materiil jual beli tanah.

Apabila terjadi persyaratan Jual Beli hak atas tanah yang belum dipenuhi maka penandatanganan para pihak terhadap Akta Jual Beli hak atas tanah belum dapat dilakukan di hadapan Pejabat Pembuat Akta Tanah. Keadaan yang seperti ini tentu tidak menguntungkan atau bahkan dapat merugikan para pihak yang melakukan jual beli hak atas tanah. Keadaan tersebutmembuat pihak penjual harus menunda dulu penjualan tanahnya, agar persyaratan tersebut dapat terpenuhi. Hal yang sama juga berlaku terhadap pihak pembeli, dengan keadaan tersebut pihak pembeli juga tertunda keinginannya untuk mendapatkan hak atas tanah yang akan dibelinya. Untuk mengatasi hal tersebut, dan untuk kelancaran tertib administrasi pertanahan, maka ditemukan suatu inovasi hukum yaitu dengan dibuatnya Akta Perjanjian Pengikatan Jual Beli, meskipun isinya mengenai jual beli namun formatnya hanya sebatas perjanjian pengikatan jual beli hak atas tanah yang dilakukan di hadapan notaris. $^{8}$

Perjanjian pengikatan jual beli merupakan perjanjian bantuan yang

8 Alfiansyah, I Nyoman Nurjaya, Sihabudin, "Urgensi Perjanjian Pengikatan Jual Beli (PPJB) Hak Atas Tanah Yang Dibuat Oleh Notaris", Jurnal Hukum, Program Studi Magister Kenotariatan, Pascasarjana Fakultas Hukum Universitas Brawijaya, 2017, hal. 17 
berfungsi sebagai perjanjian pendahuluan dan bentuknya bebas. Perjanjian Pengikatan Jual Beli tanah merupakan perjanjian dengan mana kedua belah pihak saling mengikatkan diri untuk melakukan jual beli, apabila hal-hal yang belum dapat dipenuhi pada saat perjanjian pengikatan jual beli tersebut dilakukan, biasanya menyangkut belum lengkapnya persyaratan. Dalam perkara yang terjadi pada Putusan Pengadilan Negeri Denpasar Nomor 347/Pdt.G/2014/PN.Dps, Perjanjian Pengikatan Jual Beli dibuat karena syarat jual beli yaitu pinjaman Kredit di bank sebesar Rp.1.000.000.000,(satu milyar) yang disyaratkan oleh Tergugat dipenuhi oleh INW.

$$
\text { Selain adanya Perjanjian }
$$

Pengikatan Jual Beli, dalam perkara yang terdapat Putusan Pengadilan Negeri Denpasar Nomor 347/Pdt.G/2014/PN.Dps juga dibuat Akta Kuasa menjual antara Tergugat sebagai pemberi kuasa dan INW sebagai penerima kuasa. Kuasa menjual didasarkan atas ketentuan Pasal 1792 KUH Perdata, mengartikan kuasa adalah suatu perjanjian dengan mana seorang memberikan kekuasaan kepada seorang lain, yang menerimanya, untuk atas namanya menyelenggarakan suatu urusan.

Perjanjian pemberian kuasa menurut Wirjono Prodjodikoro mengemukakan bahwa "kata-kata atas nama yaitu bahwa pihak yang diberi kuasa, bertindak secara mewakili pihak yang memberi kuasa. Juga ada sepakat bahwa soal pemberian kuasa dan soal perwakilan adalah dua hal tersendiri yang tidak selalu berada bersamasama pada suatu perhubungan hukum". 9 Menurut Suryodiningrat

9 Wirjono Prodjodikoro, Asas-Asas Hukum Perdata, Sumur, Bandung, 1995, hal. 131 "pemberian kuasa adalah perjanjian di mana seorang memberi kekuasaan (kewenangan) kepada orang lain yang menerimanya untuk dan atas nama pemberi kauasa melakukan perbuatan hukum". ${ }^{10}$

Perjanjian pemberian kuasa yang dibuat tersebut mempunyai kekuatan mengikat sejak kedua belah pihak mencapai sepakat atau konsensus, sesuai dengan yang dikemukakan oleh Subekti bahwa: "Pada dasarnya perjanjian dan perikatan yang timbul karenanya itu sudah dilahirkan sejak detik tercapainya kesepakatan. Dengan perkataan lain, perjanjian itu sudah sah apabila sudah sepakat mengenai hal-hal yang pokok dan tidaklah diperlukan sesuatu formalitas". 11 Dengan tercapainya kata sepakat tersebut, menimbulkan suatu kewajiban secara timbal balik yang lebih dikenal dengan prestasi.

Berakhirnya pemberian kuasa diatur dalam Pasal 1813, 1814 dan pasal 1816 KUHPerdata. Pasal 1813 KUHPerdata menentukan "Pemberian kuasa berakhir: dengan ditariknya kembali kuasanya si kuasa; dengan pemberitahuan penghentian kuasanya oleh si kuasa; dengan meninggalnya, pengampuannya atau pailitnya si pemberi kuasa maupun si kuasa; dengan perkawinannya si perempuan yang memberikan atau menerima kuasa"

Pasal $1814 \quad$ KUHPerdata menentukan "si pemberi kuasa dapat menarik kembali kuasanya manakala itu dikehendakinya, dan jika ada alasan untuk itu memaksa si kuasa untuk mengembalikan kuasa yang dipegangnya." Pasal 1816 KUHPerdata menentukan" Pengangkatan kuasa baru,

10 Suryodiningrat, Perikatan-Perikatan Bersumber Perjanjian, Tarsito, Bandung, 1992, hal. 117.

11 Subekti, Hukum Perjanjian, Intermasa, Jakarta, 2004, hal. 15. 
untuk menjalankan suatu urusan yang sama, menyebabkan ditariknya kembali kuasa yang pertama, terhitung mulai diberitahukannya kepada orang yang belakangan ini tentang pengangkatan tersebut." Berdasarkan ketentuan tersebut maka suatu pemberian kuasa dapat berakhir karena ditariknya kuasa tersebut oleh si pemberi kuasa atau berakhir dengan pembuatan suatu kuasa baru yang diikuti dengan pemberitahuan mengenai hal tersebut kepada penerima kuasa. Pemberian kuasa juga berakhir dengan meninggalnya si pemberi kuasa.

Pengecualian terhadap ketentuan mengenai berakhirnya kuasa biasanya dilakukan dengan mengesampingkan ketentuan mengenai berakhirnya kuasa yang diatur dalam pasal 1813, 1814 dan 1816 KUHPerdata tersebut. Kuasa yang berisikan klausul yang menyatakan kuasa tersebut tidak dapat dicabut kembali dan tidak berakhir oleh karena sebab-sebab apapun juga termasuk sebab-sebab yang diatur dalam pasal 1813, 1814 dan 1816 KUHPerdata disebut dengan "kuasa mutlak".

Dalam perkara tersebut diatas Kuasa Menjual yang diberikan oleh Tergugat kepada INW telah berakhir pada saat Tergugat menarik kembali kuasanya melalui Akta Pembatalan yang dibuat dihadapan Notaris. Sehingga dengan demikian maka segala perbuatan hukum yang dilakukan oleh INW setelah dibatalkannya kuasa menjual adalah cacat hukum dan batal demi hukum. Dalam hal ini pertimbangan hukum dari Majelis Hakim sangatlah tepat dengan membatalkan pula segala perbuatan hukum yang dilakukan oleh INW.

Selanjutnya mengenai jual beli antara Tergugat dengan INW, meskipun telah memenuhi segala aspek formal dalam perjanjian jual beli hak atas tanah, diantara pengecekan sertifikat dan dibuatnya akta Jual Beli dihadapan
PPAT namun secara materiil INW bukanlah subyek hukum yang memiliki kewenangan untuk menjual tanah yang menjadi obyek sengketa. Syarat materiil dalam perjanjian jual beli antara Penggugat dengan INW tidak terpenuhi karena dalam hal ini INW bukan sebagai Penjual yang berhak, berwenang dan boleh menjual atas tanah yang bersangkutan. Dengan adanya Akta Pembatalan Perjanjian Pengikatan Jual Beli dan Akta Kuasa Menjual antara Tergugat dengan INW maka tidak terjadi peralihan hak atas tanah dari Tergugat ke INW, sehingga dengan demikian obyek sengketa adalah tetap milik dari Penggugat. Perbuatan INW menjual obyek sengketa kepada Penggugat merupakan Perbuatan Melawan Hukum sehingga dalam hal ini putusan Majelis Hakim yang menyatakan jual beli antara INW dengan Penggugat cacat hukum dan batal demi hukum adalah sudah sangat tepat.

\section{Tanggung Gugat Pejabat Pembuat Akta Tanah Atas Kerugian Penggugat Yang Timbul Dari Putusan Pengadilan Negeri Denpasar Nomor 347/Pdt.G/2014/PN.Dps}

Kata tanggung gugat banyak disamaartikan dengan tanggung jawab namun sebenarnya dapat dibedakan antara tanggung jawab yang bersifat umum responsibility dan tanggung jawab hukum liability, dapat juga dilihat dalam kamus hukum yaitu Henry Campbell Black dalam Black's Law Dictionary membedakan kedua kata tersebut. Tanggung jawab disebut responsibility sedangkan tanggung gugat disebut juga liability. Liability diartikan sebagai condition of being responsible for a a possible or actual loss, penalty, evil, expense or burden, condition which creates a duty to 
perfomact immediately or in the future. 12

Dalam teori tradisional, ada dua jenis tanggung jawab yaitu pertanggungjawaban berdasarkan kesalahan (based on fault) dan pertanggungjawaban mutlak (absolute responsibility) ${ }^{13}$. Tanggung jawab mutlak yaitu suatu perbuatan menimbulkan akibat yang dianggap merugikan oleh pembuat undangundang dan ada suatu hubungan antara perbuatan dengan akibatnya. Tiada hubungan antara keadaan jiwa si pelaku dengan akibat dari perbuatannya.

Menurut Hans Kelsen dalam teorinya tentang tanggung jawab hukum menyatakan bahwa seseorang bertanggung jawab secara hukum atas suatu perbuatan tertentu atau bahwa dia memikul tanggung jawab hukum, subyek berarti bahwa dia bertanggung jawab atas suatu sanksi dalam hal perbuatan yang bertentangan. ${ }^{14}$ Selain itu, kegagalan untuk melakukan kehatihatian yang diharuskan oleh hukum disebut kekhilafan (negligence); dan kekhilafan biasanya dipandang sebagai satu jenis lain dari kesalahan (culpa), walaupun tidak sekeras kesalahan yang terpenuhi karena mengantisipasi dan menghendaki, dengan atau tanpa maksud jahat, akibat yang membahayakan. ${ }^{15}$

Tanggung Jawab Hukum merupakan kesadaran manusia akan

${ }^{12}$ Henry Campbell Black, Black's Law Dictionary, Centennical Fifth Edition, West Publishing Co, St. Paul, Minn,1968, hal 13

13 Jimly Asshiddiqie dan Ali Safa'at, Teori Hans Kelsen tentang Hukum, Konstitusi Press, Jakarta, 2006, hal.61.

${ }^{14}$ Hans Kelsen, General Theory Of Law and State, Teori Umum Hukum dan Negara, Dasar-Dasar Ilmu Hukum Normatif Sebagai Ilmu Hukum Deskriptif Empirik, terjemahan Somardi, BEE Media Indonesia, Jakarta, 2007, hal 81

15 Ibid, hal.83. tingkah laku atau perbuatan yang disengaja maupun yang tidak disengaja. Tanggung jawab juga berarti berbuat sebagai perwujudan kesadaran akan kewajibannya sedangkan tanggunggugat (liability/aansprakelijkheid) merupakan bentuk spesifik dari tanggungjawab. Pengertian tanggunggugat merujuk kepada posisi seseorang atau badan hukum yang dipandang harus membayar suatu bentuk kompensasi/ganti rugi setelah adanya peristiwa hukum atau tindakan hukum $^{16}$.

Notaris/Pejabat Pembuat Akta Tanah sebagai lembaga negara yang independen adalah subyek hukum, sebagai pendukung hak dan kewajiban hukum, yang memiliki kedudukan hukum yaitu sebagai kepanjangan tangan dari pemerintah yang melayani kebutuhan masyarakat dalam pembuatan akta otentik. Sebagai subyek hukum Notaris/Pejabat Pembuat Akta Tanah dapat melakukan perbuatan hukum, yaitu perbuatan yang ada relevansinya dengan hukum atau perbuatan yang dapat menimbulkan akibat hukum. Dengan demikian, setiap bentuk dari perbuatan hukum, secara pasti akan menimbulkan akibat hukum baik yang positif maupun yang negatif. Akibat hukum yang bersifat positif tidak relevan dalam kaitannya dengan tanggung-gugat. Akibat hukum yang negatif memiliki relevansi dengan tanggung-gugat karena dapat memunculkan tuntutan dari pihak yang terkena akibat hukum yang negatif yang biasa menimbulkan kerugian dari pihak tersebut.

Produk hukum yang dikeluarkan oleh Notaris/Pejabat Pembuat Akta Tanah adalah berupa akta-akta yang memiliki sifat otentik dan memiliki

16 Peter Mahmud Marzuki, Pengantar Ilmu Hukum, Kencana Prenada Media Grup, Jakarta, 2009, hal. 258 
kekuatan pembuktian yang sempurna, sebagaimana definisi akta otentik yang disebutkan dalam Pasal 1868 KUHPerdata : "Suatu akta otentik ialah suatu akta yang di dalam bentuk yang ditentukan oleh undang-undang, dibuat oleh atau dihadapan pegawai-pegawai umum yang berkuasa untuk itu ditempat dimana akta dibuatnya". Rumusan dalam Pasal 1868 KUHPerdata tersebut selanjutnya secara Lex Specialis diatur dalam Undang-Undang Nomor 30 Tahun 2004 Tentang Jabatan Notaris sebagaimana telah diubah dengan Undang-Undang Nomor 2 Tahun 2014 Tentang Perubahan Atas UndangUndang Nomor 30 Tahun 2004 Tentang Jabatan Notaris (selanjutnya ditulis UUJN) untuk Jabatan Notaris, serta dalam Peraturan Pemerintah Nomor 37 Tahun 1998 Tentang Peraturan Jabatan Pejabat Pembuat Akta Tanah sebagaimana telah diubah dengan Peraturan Pemerintah Nomor 24 Tahun 2016 tentang Perubahan Atas Peraturan Pemerintah Nomor 37 Tahun 1998 Tentang Peraturan Jabatan Pejabat Pembuat Akta Tanah (selanjutnya ditulis PJ PPAT).

Baik dalam UUJN maupun PJ PPAT, Notaris/ Pejabat Pembuat Akta Tanah dirumuskan sebagai Pejabat Umum yang berwenang untuk membuat akta otentik. Dalam hal ini yang dimaksud berwenang adalah meliputi berwenang terhadap orangnya, yaitu untuk kepentingan siapa akta itu dibuat atau dikehendaki oleh orang yang berkepentingan. Berwenang terhadap aktanya, yaitu yang berwenang membuat akta otentik mengenai semua perbuatan, perjanjian dan ketetapan yang diharuskan Undang-Undang atau yang dikehendaki yang bersangkutan, serta berwenang terhadap waktunya dan berwenang terhadap tempatnya, yaitu sesuai tempat kedudukan dan wilayah Jabatan Pejabat yang bersangkutan dan menjamin kepastian waktu para penghadap yang tercantum dalam akta, ${ }^{17}$ selain memenuhi syarat yang telah ditentukan agar suatu akta menjadi otentik, seorang Notaris/Pejabat Pembuat Akta Tanah dalam melaksanakan tugasnya tersebut wajib. ${ }^{18}$ Melaksanakan tugasnya dengan penuh disiplin, professional dan integritas moralnya tidak boleh diragukan, apa yang tertuang dalam awal dan akhir akta yang menjadi tanggungjawab Notaris/Pejabat Pembuat Akta Tanah adalah ungkapan yang mencerminkan keadaan yang sebenar-benarnya pada saat pembuatan akta.

Dalam kaitannya dengan Putusan Pengadilan Negeri Denpasar Nomor 347/Pdt.G/2014/PN.Dps,

Notaris/Pejabat Pembuat Akta Tanah yang membuat Akta Jual Beli antara Penggugat dengan INW dalam posisi yang rawan untuk terseret kedalam gugatan baik perdata maupun pidana karena dengan akta yang dibuatnya mengakibatkan terjadinya peralihan kepemilikan hak atas tanah milik Tergugat kepada Penggugat meskipun sebelumnya telah dibalik nama menjadi atas nama INW terlebih dahulu.

Notaris/Pejabat Pembuat Akta Tanah dalam menjalankan tugas jabatannya berada pada ranah kebenaran formil. Dalam hal ini apa yang disampaikan oleh para penghadap harus dianggap benar adanya. Dalam Yurisprudensi Mahkamah Agung dalam Putusan Mahkamah Agung Nomor 702 K/Sip/1973 Tanggal 5 September 1973 yang menyatakan "...Notaris fungsinya hanya mencatatkan /menuliskan apa-apa

${ }^{17}$ Habib Adjie, Meneropong Khasanah Notaris dan PPAT Indonesia, Citra Aditya Bakti, Bandung, 2009, hal. 14

${ }^{18}$ Tan Thong Kie, Studi Notariat-Serba Serbi Praktek Notaris, Ichtiar Baru Van Hoeve, Jakarta, 2000 , hal. 166. 
yang dikehendaki dan dikemukakan oleh para pihak yang menghadap Notaris tersebut. Tidak ada kewajiban bagi Notaris untuk menyelidiki secara materiil apa-apa (hal-hal) yang dikemukakan oleh penghadap di hadapan Notaris tersebut".

Selanjutnya dalam Yurisprudensi Mahkamah Agung Republik Indonesia Nomor 385 K/Pid/2006 terdapat kesesuaian bahwa Notaris tidak berwenang untuk mengkaji sah atau tidaknya Surat Kuasa di bawah tangan. Notaris dalam membuat akta hanya didasarkan kepada bukti formal saja dan tidak ada kewajiban untuk menyelidiki secara materiil alat bukti yang diajukan para penghadap sebagai dasar dibuatnya akta. Notaris dalam hal ini bukanlah pihak di dalam akta, sehingga apabila terdapat bukti palsu yang digunakan oleh penghadap dalam pembuatan akta maka menjadi tanggung jawab dari para penghadap dan tanggung jawab pidana tidak dapat dibebankan kepada Notaris.

Dari rumusan tersebut diatas maka apabila dikaitkan dengan Putusan Pengadilan Negeri Denpasar Nomor 347/Pdt.G/2014/PN.Dps, maka dalam hal ini Notaris/Pejabat Pembuat Akta Tanah yang membuat Akta Jual Beli antara INW dengan Penggugat tidak dapat dimintakan tanggung gugat atas kerugian yang terjadi akibat dinyatakannya akta tersebut cacat hukum dan batal demi hukum. Notaris/Pejabat Pembuat Akta Tanah dalam hal ini telah melakukan tugas jabatannya dengan benar dan dalam membuat akta telah sesuai dengan datadata formil yang disampaikan oleh INW kepada Notaris/Pejabat Pembuat Akta Tanah yang bersangkutan. Mengenai keterangan palsu yang disampaikan oleh INW yang menyatakan bahwa obyek sengketa adalah miliknya sesuai dengan sertifikat yang telah dibalik nama atas nama INW sepenuhnya menjadi tanggung jawab INW baik secara perdata maupun pidana. Notaris/Pejabat Pembuat Akta Tanah dalam hal ini tidak berkewajiban untuk mencari kebenaraan materiil atas data-data yang disampaikan oleh INW sehingga Notaris/Pejabat Pembuat Akta Tanah tidak dapat dimintai tanggung gugat atas kerugian yang terjadi.

\section{PENUTUP}

Jual beli hak atas tanah harus memenuhi syarat materiil yaitu pertama, penjual berhak, berwenang dan boleh menjual atas tanah yang bersangkutan, kedua, pembeli merupakan subyek hukum yang diperbolehkan untuk memiliki hak atas tanah yang dibelinya, ketiga, hak atas tanah yang dapat diperjualbelikan karena memang milik sah penjual, tidak sedang berada dalam perselisihan. Adanya pembatalan perjanjian pengikatan jual beli dan pembatalan pemberian kuasa menjual mengakibatkan penerima kuasa tidak berwenang melakukan segala bentuk perbuatan hukum atas nama pemberi kuasa dan segala perbuatan hukum yang dilakukan oleh penerima kuasa atas nama pemberi kuasa setelah adanya pembatalan adalah cacat hukum dan batal demi hukum.

Notaris/Pejabat Pembuat Akta Tanah dalam membuat akta hanya didasarkan kepada bukti formal saja dan tidak ada kewajiban untuk menyelidiki secara materiil alat bukti yang diajukan para penghadap sebagai dasar dibuatnya akta. Notaris/Pejabat Pembuat Akta Tanah dalam hal ini bukanlah pihak di dalam akta, sehingga apabila terdapat keterangan palsu yang disampaikan oleh penghadap dalam pembuatan akta maka menjadi tanggung jawab dari para penghadap sendiri baik secara perdata maupun pidana. 


\section{DAFTAR PUSTAKA}

Alfiansyah, I Nyoman Nurjaya, Sihabudin, "Urgensi Perjanjian Pengikatan Jual Beli (PPJB) Hak Atas Tanah Yang Dibuat Oleh Notaris", Jurnal Hukum, Program Studi Magister Kenotariatan, Pascasarjana Fakultas Hukum Universitas Brawijaya, 2017

Boedi Harsono, Hukum Agraria Indonesia (Sejarah Pembentukan Undang-Undang Pokok Agraria Isi dan Pelaksanaannya), Jilid I Hukum Tanah Nasional, Djambatan, Jakarta, 2008

Habib Adjie, Meneropong Khasanah Notaris dan PPAT Indonesia, PT. Citra Aditya Bakti, Bandung, 2009

Hans Kelsen, General Theory Of Law and State, Teori Umum Hukum dan Negara, Dasar-Dasar Ilmu Hukum Normatif Sebagai Ilmu Hukum Deskriptif Empirik, terjemahan Somardi, BEE Media Indonesia, Jakarta, 2007

Hatta Isnaini Wahyu Utomo, "Hukum Tanah Nasional : Bahan Diskusi Dalam Persiapan Menghadapi Ujian Pejabat Pembuat Akta Tanah 2017", Makalah, disampaikan pada acara Persiapan Menghadapi Ujian PPAT 2017, Universitas Narotama Surabaya, Oktober 2017

Henry Campbell Black, Black's Law Dictionary, Centennical Fifth Edition, West Publishing Co, St. Paul, Minn, 1968

Jimly Asshiddiqie dan Ali Safa'at, Teori Hans Kelsen tentang Hukum, Konstitusi Press, Jakarta, 2006

Peter Mahmud Marzuki, Pengantar Ilmu Hukum, Kencana Prenada Media Grup, Jakarta, 2009,
---, Penelitian Hukum, Kencana Prenada Media, Jakarta, 2010

Riduan Syahrani, Seluk Beluk dan AsasAsas Hukum Perdata, Alumni, Bandung, 1989

Rusli Muhammad, Hukum Acara Pidana Kontemporer, Citra Aditya Bakti, Bandung, 2010

Subekti, Hukum Perjanjian, Intermasa, Jakarta, 2004

Sudikno Mertodikusumo, Hukum Acara Perdata, Liberty, Yogyakarta, 1998

Suryodiningrat, Perikatan-Perikatan Bersumber Perjanjian, Tarsito, Bandung, 1992, hal. 117.

Tan Thong Kie, Studi Notariat-Serba Serbi Praktek Notaris, Ichtiar Baru Van Hoeve, Jakarta, 2000

Wirjono Prodjodikoro, Asas-Asas Hukum Perdata, Sumur, Bandung, 1995 